\title{
KAUSALITAS EKONOMI MAKRO DAN GLOBAL TERHADAP PASAR MODAL INDONESIA
}

\author{
R. Adisetiawan \\ Faculty of Economics, University of Batanghari \\ r.adisetiawan@yahoo.co.id
}

\begin{abstract}
This study aims to determine causality macroeconomic variables and the influence of the Indonesian capital market during the period 2001-2017 by means of Granger causality test statistics and test of Multiple Linear Regression. The results of this study revealed that during the period 2001-2017 there is a relationship of causality between the money supply (M2) with the Indonesia Stock Exchange composite index, but there is no causal relationship between the BI rate, inflation, the price of crude oil, gold, exchange rate IDR/USD, Dow Jones and Nikkei 225 index on the Indonesia Stock Exchange composite index over the same period. The results of model testing research at $99 \%$ confidence level, obtained adjusted $R$-square values simultaneously at $98.4 \%$, meaning that changes in the macro economy is able to provide a very significant variation in movement patterns of stock price index in Indonesia's capital market. This is also evidenced by the magnitude of the correlation values obtained in the model by $99.3 \%$, meaning that there is a very close relationship between macroeconomic variables of the Indonesian capital market. However, the partial rate of inflation that occurred in Indonesia in the period 2001-2017 did not have a significant influence on the movement of stock market indices of Indonesia.
\end{abstract}

Keywords: JCI, macroeconomic, globalization

\section{PENDAHULUAN}

Pasar modal merupakan salah satu instrumen ekonomi dewasa ini yang mengalami perkembangan sangat pesat. Pasar modal merupakan indikator kemajuan perekonomian suatu negara serta menunjang ekonomi negara yang bersangkutan (Ang, 1997). Pasar Modal memiliki peran penting bagi perekonomian suatu negara karena pasar modal menjalankan dua fungsi, yaitu pertama sebagai sarana bagi pendanaan usaha atau sebagai sarana bagi perusahaan untuk mendapatkan dana dari masyarakat pemodal atau investor (Husnan, 2004); (Adisetiawan dan Surono, 2016).

Di Indonesia, investor yang berminat untuk berinvestasi di pasar modal dapat berinvestasi di Bursa Efek Indonesia. Salah satu indikator pergerakan harga saham di Bursa Efek Indonesia adalah indeks harga saham gabungan (IHSG), karena indeks ini berisi atas seluruh saham yang tercatat di Bursa Efek Indonesia (Murwaningsari, 2008); (Adisetiawan dan Surono, 2016). Oleh karena itu melalui pergerakan IHSG, seorang investor dapat melihat kondisi pasar apakah sedang bergairah atau lesu. Perbedaan kondisi pasar ini tentu memerlukan strategi yang berbeda dari investor dalam berinvestasi. Banyak faktor yang dapat mempengaruhi indeks saham, antara lain perubahan tingkat suku bunga bank sentral, keadaan ekonomi global, tingkat harga energi dunia, kestabilan politik suatu negara, dan perilaku investor itu sendiri (Sudjono, 2005).

Kebijakan tingkat suku bunga dikendalikan secara langsung oleh bank sentral dalam hal ini Bank Indonesia melalui BI rate. BI rate merupakan respon 
bank sentral terhadap tekanan inflasi ke depan agar tetap berada pada sasaran yang telah ditetapkan (Bank Indonesia, 2008). Perubahan BI rate sendiri dapat memicu pergerakan di pasar saham Indonesia (Novianto, 2011). Penurunan BI rate secara otomatis akan memicu penurunan tingkat suku bunga kredit maupun deposito. Bagi para investor, dengan penurunan tingkat suku bunga deposito, akan mengurangi tingkat keuntungan yang diperoleh bila dana yang mereka miliki diinvestasikan dalam bentuk deposito, karena dengan penurunan suku bunga kredit, biaya modal akan menjadi kecil, ini dapat mempermudah perusahaan untuk memperoleh tambahan dana dengan biaya yang murah untuk meningkatkan produktivitasnya. Peningkatan produktivitas akan mendorong peningkatan laba, hal ini dapat menjadi daya tarik bagi para investor untuk berinvestasi di pasar modal (Novianto, 2011); (Adisetiawan, 2017)

Inflasi merupakan salah satu faktor yang mempengaruhi perekonomian, dimana naiknya inflasi membuat turunnya daya beli masyarakat. selain faktor inflasi, jumlah uang beredar yang naik juga membuat nilai uang turun dan nilai dari barang-barang akan meningkat. Untuk mengatasi tersebut Bank Indonesia akan melakukan kebijakan moneter dengan menaikkan BI rate. Kenaikan BI rate membuat masyarakat memilih untuk menyimpan uangnya di bank demi mendapatkan return bunga bank yang memiliki resiko lebih rendah bila dibandingkan instrumen keuangan yang lain, dan hal ini akan membuat jumlah uang yang beredar akan berkurang. Pergerakan nilai tukar rupiah terhadap dollar Amerika Serikat (IDR/USD) juga merupakan faktor yang patut dicermati, dimana penguatan terhadap rupiah akan membuat pasar modal akan menguat dan sebaliknya penurunan nilai tukar IDR/USD berdampak pada turunnya harga-harga saham. Pada Agustus 2011 rupiah ditutup melemah 32,26 point dari 8.505,82 per USD pada bulan Juli 2011 menjadi 8.473,56 per USD di pasar spot dunia. Melemahnya rupiah tersebut juga direspon negatif oleh para pelaku pasar modal, dimana IHSG turun 289,07 point dari level $1.430,80$ point menjadi level $3.841,73$ point pada bulan yang sama.

Selain faktor ekonomi domestik yang telah disebut di atas, harga minyak dunia juga mempengaruhi pergerakan indeks harga saham, hal ini dibuktikan dari penelitian yang dilakukan oleh Kilian dan Park (2009) yang menyatakan harga minyak dunia memberikan dampak yang signifikan terhadap pergerakan indeks bursa saham. Selain minyak dunia, emas merupakan salah satu komoditi penting yang dapat mempengaruhi pergerakan bursa saham, karena emas merupakan salah satu alternatif investasi yang cenderung aman dan bebas resiko (Sunariyah, 2006). Oleh sebab itu, kenaikan harga emas akan mendorong penurunan indeks harga saham, karena investor yang semula berinvestasi di pasar modal akan mengalihkan dananya untuk berinvestasi di emas yang relatif lebih aman daripada berinvestasi di bursa saham, hal ini juga didukung oleh penelitian yang dilakukan Smith (2001) yang membuktikan bahwa harga emas memiliki pengaruh yang negatif terhadap indeks bursa saham di Amerika Serikat.

Perekonomian Indonesia saat ini telah terintegrasi dalam perekonomian global. Amerika Serikat dan Jepang adalah dua negara tujuan ekspor non-migas terbesar Indonesia (Bank Indonesia, 2008). Perubahan keadaan perekonomian di negara tersebut tentu akan memberikan pengaruh, baik secara langsung maupun tidak langsung, kepada Indonesia. Apabila perekonomian kedua negara tersebut mengalami keadaan resesi, ini tentu akan menyebabkan nilai ekspor non-migas Indonesia ke negara-negara tersebut ikut menurun, sebab konsumen di negara 
tersebut dalam keadaan ekonomi yang sedang resesi tentu akan mengurangi tingkat pengeluarannya. Selain merupakan negara tujuan ekspor Indonesia, kedua negara tersebut merupakan negara dengan perekonomian terbesar di dunia (Prijambodo, 2011), maka jelas bahwa perubahan keadaan ekonomi di kedua negara tersebut dapat mempengaruhi perekonomian Indonesia, baik melalui kegiatan ekspor impor barang dan jasa, aliran dana dari investor kedua negara tersebut, atau perubahan tingkat resiko bisnis di kedua negara tersebut. Salah satu variabel ekonomi yang dapat digunakan untuk mengukur kinerja perekonomian suatu negara adalah indeks saham di negara tersebut. Hal ini dimungkinkan karena ketika negara tersebut memiliki prospek perekonomian yang cerah, otomatis investor akan tertarik untuk menanamkan dananya di pasar modal negara yang bersangkutan, yang tentunya akan mendorong terjadinya masa-masa bullish yang akan mendorong pergerakan indeks saham. Demikian pula sebaliknya, ketika dirasakan suasana perekonomian suram, akan tercermin pula dalam indeks sahamnya yang akan turun (Ang, 1997); (Adisetiawan dan Surono, 2016)

Untuk Jepang, indeks saham yang akan dijadikan proksi adalah indeks Nikkei 225. Indeks Nikkei 225 dipilih dalam variabel penelitian ini karena selain perhitungan indeks ini sudah dilakukan sejak tahun 1950, indeks ini juga merupakan indeks yang paling sering digunakan di Jepang sebagai patokan kinerja bursa sahamnya (Suharti dan Mariah, 2004). Indeks pasar modal Amerika Serikat yang dapat dijadikan proksi adalah indeks Dow Jones. Indeks Dow Jones dipilih sebagai variabel dalam penelitin ini karena indeks pasar saham tertua di Amerika Serikat dan merupakan representasi dari kinerja industri terpenting di Amerika Serikat (Muharam dan Nurafni, 2008). Indeks Dow Jones yang bergerak naik, menandakan kinerja perekonomian Amerika Serikat secara umum berada pada posisi yang baik. Dengan kondisi perekonomian yang baik, akan menggerakkan perekonomian Indonesia melalui kegiatan ekspor maupun aliran modal masuk baik investasi langsung maupun melalui pasar modal (Sunariyah, 2006); (Adisetiawan, 2017). Aliran modal yang masuk melalui pasar modal tentu akan memiliki pengaruh terhadap perubahan IHSG di Indonesia.

\section{METODE}

Data penelitian ini merupakan data sekunder yang diperoleh dari website Bank Indonesia (bi.go.id) berupa data BI rate, Inflasi, dan Jumlah Uang Beredar; Statistik Pasar Modal dari website Bapepam (bapepam.go.id) berupa closing price IHSG, Indeks Dow Jones, dan Indeks Nikkei 225; website economagic.com berupa daftar harga spot pasar minyak mentah dunia standar West Texas Intermediate; dan website kitco.com berupa daftar harga spot pasar emas dunia di London; sedangkan closing price kurs IDR/USD didapat dari bursa Forex Trading and Exchange Rates Service pada website oanda.com sehingga semua data tergolong data historis. Populasi yang digunakan dalam penelitian ini adalah seluruh data BI rate, inflasi, jumlah uang beredar, kurs IDR/USD, daftar harga minyak mentah dunia dalam USD/barrel, daftar harga emas dunia dalam USD/ounce, data IHSG, Indeks Dow Jones dan Nikkei 225 dengan sampel data yang diambil selama periode pengamatan yaitu periode 2001-2017. Penentuan sampel penelitian ini menggunakan teknik judgment sampling, dimana sampel yang digunakan sengaja dipilih agar dapat mewakili populasinya dan dapat memenuhi tujuan penelitian (Jatiningsih, 2007); (Adisetiawan, 2017). 
Variabel independen dalam penelitian ini adalah BI rate, inflasi, jumlah uang beredar, harga minyak mentah dunia, harga emas dunia, kurs IDR/USD, indeks Dow Jones, dan indeks Nikkei 225. Sedangkan variabel dependennya adalah IHSG di Bursa Efek Indonesia (BEI). Analisis data dilakukan dengan menggunakan uji Kausalitas Granger dan uji Regresi Linier Berganda. Sebelum melakukan analisis kausalitas dan regresi, terlebih dahulu dilakukan uji asumsi klasik berupa uji normalitas, autokorelasi, multikolineritas dan heteroskedastisitas.

Menurut Ghozali (2006), uji normalitas bertujuan untuk menguji apakah dalam model regresi, variabel pengganggu atau residual memiliki distribusi normal. Pengujian dengan uji t dan uji $\mathrm{F}$ mengasumsikan bahwa nilai residual mengikuti distribusi normal. Kalau asumsi ini dilanggar maka uji statistik menjadi tidak valid. Uji multikolinearitas bertujuan untuk menguji apakah model regresi ditemukan adanya korelasi antar variabel bebas (independen). Autokorelasi menunjukkan adanya korelasi antara anggota sampel yang diurutkan dengan waktu. Penyimpangan ini muncul pada observasi yang menggunakan data time series. Konsekuensi dengan adanya autokorelasi dalam suatu model regresi adalah varians sampel tidak dapat menggabungkan varians populasinya, pengujian dilakukan dengan Durbin Watson Test. Uji heteroskedastisitas bertujuan menguji apakah dalam model regresi terjadi ketidaksamaan varians dari residual satu pengamatan ke pengamatan yang lain. Jika varians dari residual satu pengamatan ke pengamatan lain tetap, maka disebut homoskedastisitas dan jika berbeda disebut heteroskedastisitas. Model yang baik adalah yang homoskedastisitas atau tidak terjadi heteroskedastisitas.

Setelah variabel-variabel penelitian memenuhi uji prasyarat asumsi klasik tersebut di atas selanjutnya dilakukan uji kausalitas granger dan regresi serta pengujian hipotesis. Pengujian hipotesis dilakukan melalui uji t, uji $\mathrm{F}$ dan koefisien determinasi (Adjusted $R^{2}$ ). Uji t merupakan pengujian parsial regresi yang dimaksudkan untuk melihat apakah variabel bebas secara individu mempunyai pengaruh terhadap variabel tidak bebas dengan asumsi variabel lainnya konstan. Uji $\mathrm{F}$ pada dasarnya menunjukkan apakah semua variabel independen atau bebas yang dimasukkan dalam model mempunyai pengaruh secara simultan terhadap variabel dependen atau terikat. Koefisien determinasi (Adjusted $R^{2}$ ) pada intinya mengukur seberapa jauh kemampuan model dalam menerangkan variasi variabel dependen.

\section{HASIL}

\section{Uji Stasioneritas}

Hasil pengujian unit root test dengan menggunakan Eviews 7.1 didapatkan variabel BI rate, Inflasi, Minyak Mentah Dunia, Emas, Kurs IDR/USD, Indeks Dow Jones, Nikkei 225 dan IHSG mengalami stasioner setelah perbedaan pertama pada tingkat keyakinan 99\%. Sementara variabel Jumlah Uang Beredar mengalami stasioner setelah perbedaan kedua pada tingkat keyakinan $99 \%$.

\section{Uji Asumsi Klasik}

Hasil uji asumsi klasik dengan menggunakan Eviews 7.1 dapat dijelaskan sebagai berikut: Uji normalitas dengan metode Ordinary Least Squares (OLS) pada semua model hipotesis yang diajukan diperoleh nilai Jarque Bera (JB) < Chi-square Distribution Table $\left(\chi^{2}\right)$; sehingga dapat dikatakan bahwa residual pada model hipotesis telah terdistribusi secara normal. Hasil pengujian pada OLS juga 
didapat bahwa nilai $\mathrm{R}$-squared yang tinggi yaitu sebesar 0,985 sementara nilai signifikansi parameter yang rendah pada masing-masing variabel independen, ini berarti model regresi terbebas dari gangguan multikolineritas. Uji Autokorelasi dengan Durbin-Watson Test pada model hipotesis diperoleh nilai yang berada diantara -2 dan +2 , sehingga dapat dikatakan bahwa semua model hipotesis yang diajukan tidak memiliki masalah autokolerasi. Uji heteroskedastisitas dengan uji White diperoleh hasil bahwa variabel BI rate, Harga Minyak Dunia, Kurs IDR/USD, dan Indeks Nikkei 225 terhadap IHSG memiliki nilai $\mathrm{n}^{* \mathrm{R}}$ square > Chi-square Distribution Table $\left(\chi^{2}\right)$; berarti tidak adanya heteroskedastik pada hubungan variabel tersebut, sebaliknya; pada variabel Inflasi, Jumlah Uang Beredar, Harga Emas Dunia, dan Indeks Dow Jones terhadap IHSG terdapat adanya heteroskedastik, akan tetapi karena penelitian ini bukan untuk peramalan atau forecasting, maka model penelitian tetap dilanjutkan.

\section{Penentuan Panjang Lag Optimal}

Menurut Novita dkk (2009), pemilihan model dilakukan menggunakan lag yang meminimumkan kriteria dari kriteria Akaike Information Criterion (AIC), kriteria Schwarz Information Criterion (SIC), kriteria Hannan-Quinn Information Criterion (HQ), kriteria Final Prediction Error (FPE) dan memaksimumkan kriteria dari uji Likelihood Ratio (LR). Berdasarkan hasil pengujian dengan menggunakan Eviews 7.1 seperti yang terlihat pada tabel 1, didapat panjang lag yang paling optimal pada lag 12, karena dari 6 kriteria statistik pada lag 12, yang signifikan pada level $5 \%$ terdapat 5 kriteria.

Tabel 1.

Panjang Lag dengan Metode Varians Autoregresive

\begin{tabular}{ccccccc}
\hline Lag & LogL & LR & FPE & AIC & SC & HQ \\
\hline 0 & 1532,453 & NA & $7,60 \mathrm{E}-23$ & $-25,39088$ & $-25,18182$ & $-25,30598$ \\
1 & 2813,542 & 2348,662 & $1,57 \mathrm{E}-31$ & $-45,39236$ & $-43,30174 *$ & $-44,54335$ \\
2 & 2929,473 & 195,1518 & $8,95 \mathrm{E}-32$ & $-45,97456$ & $-42,00238$ & $-44,36144$ \\
3 & 2976,296 & 71,79493 & $1,67 \mathrm{E}-31$ & $-45,40494$ & $-39,55120$ & $-43,02771$ \\
4 & 3038,037 & 85,40772 & $2,56 \mathrm{E}-31$ & $-45,08394$ & $-37,34866$ & $-41,94261$ \\
5 & 3112,524 & 91,86762 & $3,44 \mathrm{E}-31$ & $-44,97540$ & $-35,35855$ & $-41,06995$ \\
6 & 3226,862 & 123,8660 & $2,64 \mathrm{E}-31$ & $-45,53103$ & $-34,03263$ & $-40,86148$ \\
7 & 3305,083 & 73,00613 & $4,31 \mathrm{E}-31$ & $-45,48471$ & $-32,10475$ & $-40,05105$ \\
8 & 3378,364 & 57,40399 & $9,45 \mathrm{E}-31$ & $-45,35607$ & $-30,09456$ & $-39,15830$ \\
9 & 3522,056 & 91,00500 & $8,80 \mathrm{E}-31$ & $-46,40094$ & $-29,25787$ & $-39,43906$ \\
10 & 3750,760 & 110,5402 & $3,28 \mathrm{E}-31$ & $-48,86267$ & $-29,83804$ & $-41,13668$ \\
11 & 4045,431 & 98,22341 & $9,96 \mathrm{E}-32$ & $-52,42384$ & $-31,51766$ & $-43,93374$ \\
12 & 4681,488 & $116,6105^{*}$ & $7,73 \mathrm{E}-34 *$ & $-61,67480 *$ & $-38,88705$ & $-52,42059 *$ \\
\hline
\end{tabular}

*= signifikan pada level $5 \%$

\section{Granger Causality Test}

Hasil uji Granger Causality pada lag 12 dengan menggunakan Eviews 7.1 diperoleh hasil bahwa terdapat hubungan kausalitas antara Jumlah Uang Beredar dengan IHSG; terdapat hubungan yang searah antara BI rate, Harga Minyak Dunia, dan Kurs IDR/USD dengan IHSG; dan tidak terdapat hubungan timbal balik ataupun yang searah pada hubungan Inflasi, Harga Emas Dunia, Indeks Dow Jones dan Nikkei 225 dengan IHSG. 
Analisis Regresi Berganda

Tabel 2

Hasil Uji Analisis Regresi

\begin{tabular}{lrrrrr}
\hline \multicolumn{1}{c}{ Variabel } & Koefisien & t-hitung & Signifikansi & Tolerance & \multicolumn{1}{c}{ VIF } \\
\hline Constant & $-5,739$ & $-6,814$ & 0,000 & & \\
BI rate & $-0,288$ & $-5,817$ & 0,000 & 0,280 & 3,577 \\
Inflasi & 0,047 & 2,055 & 0,042 & 0,580 & 1,702 \\
Jumlah Uang Beredar & 0,519 & 2,632 & 0,010 & 0,011 & 8,455 \\
Harga Minyak Mentah & 0,171 & 3,523 & 0,001 & 0,120 & 8,364 \\
Harga Emas Dunia & 0,684 & 4,637 & 0,000 & 0,010 & 9,292 \\
Kurs IDR/USD & $-0,904$ & $-4,664$ & 0,000 & 0,493 & 2,027 \\
Indeks Dow Jones & 0,418 & 3,341 & 0,001 & 0,227 & 4,400 \\
Indeks Nikkei 225 & 0,591 & 7,181 & 0,000 & 0,240 & 4,174 \\
R & & 0,993 & F-hitung & & 1041,072 \\
R-squared & & 0,985 & Sig. F & & 0,000 \\
Adjusted R-square & & 0,984 & DW & & 0,516 \\
\hline
\end{tabular}

Hasil pengujian secara parsial (uji t) dengan menggunakan SPSS 19.0 pada tabel 1 menjelaskan bahwa; selama periode 2001-2017 terdapat pengaruh yang signifikan antara variabel BI rate, Jumlah Uang Beredar, Harga Minyak Mentah Dunia, Harga Emas, Kurs IDR/USD, Indeks Dow Jones, dan Nikkei 225 terhadap IHSG di Bursa Efek Indonesia, karena dari masing-masing pengujian pada variabel independen tersebut mempunyai nilai t-hitung $>\mathrm{t}$-tabel dan nilai sig. $\mathrm{t}<$ $\alpha(0,01)$. Hasil pengujian tersebut juga diperoleh bahwa variabel BI rate dan Kurs IDR/USD memiliki pengaruh negatif terhadap IHSG selama periode pengamatan. Sementara variabel Inflasi tidak mempunyai pengaruh terhadap IHSG selama periode 2001-2017, karena mempunyai nilai t-hitung < t-tabel dan nilai sig. $\mathrm{t}>\alpha$ $(0,01)$.

Jika uji $t$ merupakan pengujian variabel bebas secara parsial mempengaruhi variabel terikat, maka uji $\mathrm{F}$ menguji apakah variabel bebas yang dimasukkan dalam model mempunyai pengaruh secara simultan terhadap variabel terikat. Dari hasil pengujian Anova menghasilkan F-hitung sebesar 1041,072 > Ftabel $(2,66)$ dan nilai sig. $F(0,000)<\alpha(0,01)$; maka model regresi dapat digunakan untuk memprediksi nilai IHSG atau dapat dinyatakan bahwa variabel BI rate, Inflasi, Jumlah Uang Beredar, Harga Minyak Dunia, Harga Emas Dunia, Kurs IDR/USD, Indeks Dow Jones dan Indeks Nikkei 225 secara simultan berpengaruh terhadap IHSG selama periode 2001-2017.

\section{Koefisien Determinasi (Adjusted $\boldsymbol{R}^{2}$ )}

Dari hasil pengujian didapat nilai adjusted $R$ square sebesar 0,984; yang berarti variasi IHSG dapat dijelaskan oleh variasi dari kedelapan variabel BI rate, Inflasi, Jumlah Uang Beredar, Harga Minyak Dunia, Harga Emas Dunia, Kurs IDR/USD, Indeks Dow Jones dan Indeks Nikkei 225, sedangkan sisanya sebesar $1,6 \%$ dijelaskan oleh perubahan variabel lain di luar model penelitian. Nilai koefisien korelasi (R) diperoleh sebesar 0,993 menunjukkan bahwa hubungan antara variabel independen terhadap variabel dependen adalah signifikan (kuat) yaitu sebesar $99,3 \%$. 


\section{Pengujian Hipotesis dan Pembahasan}

Dari serangkaian pengujian yang dimulai dari uji stasioneritas, uji asumsi klasik, uji panjang lag, uji Granger Causality, dan uji Regresi Linier Berganda, maka didapatkan hasil sebagai berikut:

a) Hubungan BI rate dengan IHSG

Hipotesa pertama yang menyatakan bahwa diduga ada hubungan timbal balik antara IHSG dengan BI rate selama periode 2001-2017 tidak terbukti, karena dari hasil analisis Granger Causality diperoleh bahwa tidak terdapat hubungan timbal balik antara BI rate dengan IHSG, tetapi IHSG dipengaruhi BI rate. Hasil analisis Regresi Berganda secara parsial (uji t) juga membuktikan bahwa BI rate berpengaruh negatif terhadap IHSG selama periode 2001-2017.

$\mathrm{BI}$ rate secara umum menunjukkan penurunan, penurunan tingkat suku bunga akan mendorong kenaikan indeks harga saham di pasar modal (Nugroho, 2008). Pada saat terjadi kenaikan suku bunga, para investor akan berupaya untuk memindahkan investasinya pada aset yang mampu memberikan return yang lebih besar, dengan cara menarik investasinya dari pasar modal dan menanamkan pada pasar uang (Madura, 2000). Menurunnya minat investor untuk berinvestasi di pasar modal akan berakibat pada menurunnya hargaharga saham, yang selanjutnya akan berimbas pada menurunnya indeks pasar. Hasil penelitian ini mendukung penelitian yang dilakukan sebelumnya, diantaranya penelitian yang dilakukan Setyastuti (2001) dalam Murwaningsari (2008), Hermawan dan Manurung (2002), Theresia (2002) dalam Pratikno (2009), Bernanke dan Kuttner (2004), Valadkhani dkk (2006), Handayani (2007), Nugroho (2008), dan Adisetiawan (2011); penelitian tersebut mengungkapkan bahwa tingkat suku bunga memiliki pengaruh yang negatif terhadap pasar saham. Pada penelitian Adisetiawan (2012) juga membuktikan bahwa tingkat suku bunga mempunyai pengaruh negatif terhadap tingkat pengembalian (return) saham, hal ini dikarenakan besarnya kenaikan tingkat suku bunga di Indonesia masih di bawah tingkat keuntungan yang didapatkan oleh para investor, sehingga para investor lebih bertahan untuk berinvestasi di pasar saham.

b) Hubungan Inflasi dengan IHSG

Hipotesa kedua yang menyatakan bahwa diduga ada hubungan timbal balik antara IHSG dengan inflasi selama periode 2001-2017 tidak terbukti, karena dari hasil analisis Granger Causality diperoleh bahwa tidak terdapat hubungan timbal balik antara Inflasi dengan IHSG. Hasil analisis Regresi Berganda secara parsial (uji t) juga membuktikan bahwa Inflasi tidak mempunyai pengaruh terhadap IHSG selama periode 2001-2017.

Tingkat inflasi mempunyai kemampuan di dalam penurunan daya beli konsumen terhadap suatu produk sehingga dapat mengurangi laba yang dihasilkan oleh perusahaan, sehingga tetap dipergunakan dalam penelitian ini, namun selama periode pengamatan inflasi tidak mempunyai pengaruh terhadap indeks pasar modal, hal ini dimungkinkan secara relatif laju inflasi cukup rendah bahkan tidak sampai dua digit, kemungkinan lain banyaknya para spekulan yang terjun di pasar modal tidak memperhatikan besarnya laju inflasi, karena saat ini tingkat inflasi cukup rendah (Jatiningsih, 2007 dalam Adisetiawan, 2011). Hasil penelitian ini konsisten dengan penelitian sebelumnya, diantaranya penelitian Hermanto dan Manurung (2002), Erawati dan Richard (2002), Utami dan Rahayu (2003), Sirait (2004), Widjaja (2004), 
Jatiningsih (2007), Nugroho (2008), Pratikno (2009), dan Adisetiawan (2011); membuktikan bahwa inflasi tidak mempunyai pengaruh terhadap pasar modal. Namun pada penelitian Adisetiawan (2012) mengungkapkan bahwa tingkat inflasi di Indonesia mempunyai hubungan timbal balik dengan BI rate, hal ini membuktikan bahwa kondisi perekonomian Indonesia saat ini dalam kondisi yang stabil. Bank Indonesia menggunakan BI rate sebagai salah satu instrumen untuk mengendalikan inflasi. Apabila inflasi dirasakan cukup tinggi, maka BI akan menaikkan BI rate untuk meredam kenaikan inflasi.

c) Hubungan Jumlah Uang Beredar (M2) dengan IHSG

Hipotesa ketiga yang menyatakan bahwa diduga ada hubungan timbal balik antara IHSG dengan Jumlah Uang Beredar selama periode 2001-2017 terbukti, karena dari hasil analisis Granger Causality diperoleh bahwa terdapat hubungan timbal balik antara Jumlah Uang Beredar dengan IHSG. Hasil analisis Regresi Berganda secara parsial (uji t) juga membuktikan bahwa Jumlah Uang Beredar mempunyai pengaruh positif terhadap IHSG selama periode 2001-2017.

Hasil penelitian ini konsisten dengan penelitian Hermanto dan Manurung (2002), Sulistiyo (2004), Sudjono (2005), Pasaribu (2008), dan Nugroho (2008) yang menyatakan Jumlah Uang Beredar (M2) berpengaruh positif terhadap pasar modal. Penelitian ini juga konsisten dengan penelitian Adisetiawan (2011) sebelumnya, yang mengungkapkan bahwa terdapat hubungan simultan jangka panjang dalam vektor terkointegrasi antara Jumlah Uang Beredar (M2) dengan indeks pasar saham, hal ini dikarenakan uang yang beredar di Indonesia sudah banyak dimanfaatkan masyarakat untuk tujuan berinvestasi di pasar saham atau obligasi, sehingga mempengaruhi pada pergerakan indeks saham di pasar modal.

d) Hubungan Harga Minyak Dunia dengan IHSG

Hipotesa keempat yang menyatakan bahwa diduga ada hubungan timbal balik antara IHSG dengan Harga Minyak Mentah Dunia selama periode 2001-2017 tidak terbukti, karena dari hasil analisis Granger Causality diperoleh bahwa tidak terdapat hubungan timbal balik antara Harga Minyak Dunia dengan IHSG, tetapi IHSG dipengaruhi Harga Minyak Mentah Dunia selama periode 2001-2017. Hasil analisis Regresi Berganda secara parsial (uji t) juga membuktikan bahwa Harga Minyak Dunia mempunyai pengaruh positif terhadap IHSG selama periode 2001-2017.

Hal ini dikarenakan selama periode pengamatan 2001-2017, kenaikan harga minyak disebabkan bukan karena berkurangnya penawaran, tetapi karena meningkatnya permintaan, seperti halnya kenaikan harga minyak dunia saat ini disebabkan oleh terganggunya supply minyak akibat konflik geopolitik di Afrika Utara dan Timur Tengah, gagalnya kesepakatan negara-negara anggota OPEC untuk menambah suplai minyak pada pertemuan OPEC bulan Juni 2011 memicu kenaikan harga minyak dunia (Bank Indonesia, 2011). Pada penelitian Sriwardani (2009) menyebutkan bahwa harga minyak saat ini menjadi salah satu indikator ekonomi global yang cukup signifikan terutama terhadap AS dan China. Naiknya harga minyak mentah mencerminkan membaiknya proses pemulihan ekonomi di negara maju, seperti AS yang berdampak makin kuatnya pertumbuhan ekonomi di Asia, sehingga akan memberikan sentimen positif bagi bursa saham global. Krisis ekonomi global yang terjadi dewasa ini, telah mengubah fundamental penggerak saham di 
pasar modal. Sejak minyak mentah mencapai harga puncaknya pada tahun 2008 yang kemudian menurun draktis, berdampak pada bursa saham global termasuk IHSG yang terus bergerak mengiringi pergerakan harga minyak hingga sampai saat ini. Naiknya harga minyak mentah dunia mendongkrak harga saham, hal ini dikarenakan investor beranggapan dengan naiknya hargaharga energi merupakan pertanda meningkatnya permintaan global, yang berarti membaiknya pemulihan ekonomi global pasca krisis. Sebaliknya, jika harga energi turun mencerminkan melemahnya pemulihan ekonomi global. Hal ini berdampak di Indonesia yang ditandai dengan banyaknya emiten yang melebarkan sayapnya ke bisnis pertambangan dan agrikultural yang terindikasi oleh pergerakan harga minyak dunia, yang secara tidak langsung berpengaruh terhadap pergerakan IHSG, sehingga pergerakan harga minyak dunia berkorelasi positif dengan bursa saham khususnya IHSG (Sidarta, 2010). Penelitian Narayan dan Narayan (2009) juga menyatakan bahwa fluktuatif harga minyak mentah dunia merupakan suatu indikasi yang mempengaruhi pasar modal suatu negara. Secara tidak langsung kenaikan harga minyak mentah dunia akan berimbas pada sektor ekspor dan impor suatu negara. Bagi negara pengekspor minyak, kenaikan harga minyak mentah dunia merupakan keuntungan tersendiri bagi perusahaan, karena harga yang tinggi membuat investor cenderung menginvestasikan dananya ke berbagai sektor komoditi minyak dan pertambangan. Namun jika harga minyak turun para investor cenderung melakukan aksi ambil untung (taking profit) dengan cara menjual sahamnya. Selanjutnya Narayan dan Narayan (2009) dalam penelitiannya juga menyatakan bahwa pertumbuhan ekonomi nasional tidak terlepas dari perkembangan ekonomi dunia. Dalam tahun 2007 ekonomi dunia tumbuh 5,0\% dengan Asia sebagai penggerak ekonomi dunia, yang didorong oleh China, India dan negara-negara emerging market lainnya. Tingginya pertumbuhan ekonomi dunia turut meningkatkan permintaan minyak dunia. Sementara keterbatasan produksi terutama negara non OPEC serta kuatnya komitmen negara-negara anggota OPEC untuk menjaga tingkat produksinya. Memasuki tahun 2008, tekanan eksternal berupa tingginya harga minyak dunia membuat IHSG di Bursa Efek Indonesia turun 4,3\% pada periode yang sama. Pada akhir Juli 2008 ketika harga minyak dunia mencapai US\$ 130 per barrel membuat IHSG di Bursa Efek Indonesia menurun menjadi 2.304,5 point atau $16,1 \%$ lebih rendah dibandingkan akhir tahun 2007. Hasil penelitian ini mendukung penelitian yang dilakukan oleh Hayo dan Kutan (2004) yang menunjukkan bahwa harga minyak dunia berpengaruh positif terhadap pasar modal, dan penelitian Sriwardani (2009) yang menyatakan bahwa kenaikan harga minyak akibat meningkatnya permintaan akan mendorong kenaikan indeks harga saham.

e) Hubungan Harga Emas Dunia dengan IHSG

Hipotesa kelima yang menyatakan bahwa diduga ada hubungan timbal balik antara IHSG dengan Harga Emas Dunia selama periode 2001-2017 tidak terbukti, karena dari hasil analisis Granger Causality diperoleh bahwa tidak terdapat hubungan timbal balik antara Harga Emas Dunia dengan IHSG, tetapi IHSG dipengaruhi Harga Emas Dunia selama periode 2001-2017. Hasil analisis Regresi Berganda secara parsial (uji t) juga membuktikan bahwa Harga Emas Dunia mempunyai pengaruh positif terhadap IHSG selama periode 2001-2017. 
Hal ini disebabkan selama periode pengamatan perekonomian dunia senantiasa mengalami pertumbuhan setiap tahunnya. Peningkatan pertumbuhan ekonomi tentu akan meningkatkan pendapatan rata-rata masyarakat. Di Indonesia selama periode pengamatan pendapatan per kapita masyarakat Indonesia mengalami peningkatan yaitu US\$ 1.980 pada tahun 2008 dan meningkat menjadi US\$ 2.950-3.000 pada tahun 2012 (Bank Indonesia, 2008), berarti tingkat kesejahteraan masyarakat Indonesia secara umum meningkat. Peningkatan kesejahteraan ini mengakibatkan masyarakat memiliki kesempatan untuk melakukan diversifikasi investasi untuk mengurangi resiko. Salah satu keunggulan dari berinvestasi pada emas adalah nilai yang cenderung naik, selain itu pemilik emas dapat dengan mudah menjual emasnya kapan saja bila membutuhkan dana tanpa mengalami kerugian yang besar. Hasil penelitian ini mendukung Twite (2002) bahwa kenaikan harga emas akan mendorong kenaikan indeks harga saham, karena selain minyak, emas merupakan salah satu komoditi penting yang dapat mempengaruhi pergerakan bursa saham. Hal ini didasari bahwa emas merupakan salah satu alternatif investasi yang cenderung aman dan bebas resiko (Sunariyah, 2006). Selanjutnya dalam penelitian Sunariyah (2006) menyebutkan bahwa emas banyak dipilih sebagai salah satu bentuk investasi karena nilainya cenderung stabil dan naik, dan sangat jarang sekali harga emas turun.

f) Hubungan Kurs IDR/USD dengan IHSG

Hipotesa keenam yang menyatakan bahwa diduga ada hubungan timbal balik antara Kurs IDR/USD dengan IHSG tidak terbukti, karena dari hasil analisis Granger Causality diperoleh bahwa tidak terdapat hubungan timbal balik antara Kurs IDR/USD dengan IHSG, tetapi IHSG dipengaruhi Kurs IDR/USD selama periode 2001-2017. Hasil analisis Regresi Berganda secara parsial (uji t) juga membuktikan bahwa Kurs IDR/USD mempunyai pengaruh negatif terhadap IHSG selama periode 2001-2017.

Pengaruh negatif Kurs IDR/USD terhadap IHSG terlihat disaat Kurs IDR/USD meningkat (rupiah melemah atau terdepresiasi) menyebabkan harga saham menurun, hal ini dikarenakan pelaku ekonomi memiliki kepercayaan bahwa otoritas moneter akan bereaksi dalam bentuk mempercepat kebijakan yang bersifat restriktif, yang akan mendorong tingkat suku bunga menguat, ketika tingkat suku bunga menguat pelaku ekonomi akan melakukan antisipasi dengan menjual saham yang dimilikinya, reaksi tersebut akan mendorong harga saham turun sehingga secara otomatis IHSG akan mengalami penurunan. Demikian juga sebaliknya, jika Kurs IDR/USD mengalami penurunan (rupiah menguat atau mengalami apresiasi), maka nilai tukar sejumlah rupiah yang diperlukan untuk membeli satu US\$ rendah. Hal ini menyebabkan investor lebih tertarik untuk menanamkan modalnya di pasar modal, karena pelaku ekonomi optimis bahwa kinerja emiten bisa tumbuh dengan baik seiring dengan menguatnya rupiah, reaksi investor tersebut akan menyebabkan harga saham mengalami kenaikan sehingga IHSG juga mengalami peningkatan (Adisetiawan, 2011). Hasil penelitian sebelumnya juga menyimpulkan bahwa ketika Kurs IDR/USD terdepresiasi, maka IHSG akan melemah. Bagi investor pelemahan nilai kurs IDR/USD menunjukkan situasi fundamental perekonomian Indonesia dalam kondisi yang suram. Prospek perekonomian suram, akan membuat investor cenderung untuk 
melepaskan saham-saham yang dimilikinya untuk menghindari resiko. Aksi jual saham ini tentunya akan mendorong pelemahan IHSG (Adisetiawan, 2012). Selama periode pengamatan diperoleh hasil bahwa nilai kurs IDR/USD dipertahankan oleh BI dalam kisaran Rp 8.500,00-Rp 10.000,00 per dollar Amerika Serikat (Bank Indonesia, 2011). Nilai kurs IDR/USD yang relatif stabil menunjukkan bahwa prospek perekonomian Indonesia cukup baik. Hal ini tercermin IHSG yang cenderung naik selama periode pengamatan.

Hasil penelitian ini memperkuat penelitian yang dilakukan Lee (1992), Hermanto dan Manurung (2002), Theresia (2002), Sitinjak (2003), Wiyani dan Widjayanto (2004), Valadkhani dkk (2006), Sa'adah dkk (2006), Murwaningsari (2008), Muharam dan Nuraini (2008), dan Pratikno (2009) yang membuktikan nilai tukar (kurs) berpengaruh negatif terhadap indeks harga saham

g) Indeks Dow Jones terhadap IHSG

Hipotesa ketujuh yang menyatakan bahwa diduga ada hubungan timbal balik antara Indeks Dow Jones dengan IHSG tidak terbukti, karena dari hasil analisis Granger Causality diperoleh bahwa tidak terdapat hubungan timbal balik antara Indeks Dow Jones dengan IHSG, tetapi IHSG dipengaruhi Indeks Dow Jones selama periode 2001-2017. Hasil analisis Regresi Berganda secara parsial (uji t) juga membuktikan bahwa Indeks Dow Jones mempunyai pengaruh positif terhadap IHSG selama periode 2001-2017.

Terdapat pengaruh positif antara indeks Dow Jones terhadap Indeks Harga Saham di Bursa Efek Indonesia (BEI) selama periode penelitian. Indeks Dow Jones merupakan indeks dengan kapitalisasi terbesar di dunia oleh karena itu pergerakan indeks Dow Jones dapat mempengaruhi hampir seluruh indeks saham secara global termasuk IHSG. Pengaruh indeks Dow Jones terhadap IHSG diperkirakan positif dalam arti kenaikan indeks Dow Jones akan mengakibatkan naiknya IHSG di Bursa Efek Indonesia (BEI), hal ini disebabkan oleh adanya sentimental positif dari para investor terhadap kondisi ekonomi dunia (Pratikno, 2009). Hal ini dapat dilihat perkembangan indeks Dow Jones yang terjadi dari Januari 2004 sampai dengan Februari 2009. Pada periode tersebut indeks Dow Jones pada awal tahun 2004 sampai akhir tahun 2007 mengalami peningkatan yang cukup signifikan. Naiknya indeks Dow Jones disebabkan adanya peningkatan terhadap fundamental makroekonomi Amerika Serikat dan dunia sehingga dapat meningkatkan indikator ekonomi Amerika Serikat seperti naiknya PDB, turunnya pengangguran, naiknya kepercayaan investor terhadap perusahaan dan neraca pembayaran yang terus surplus. Kemudian setelah krisis Subprime Morgage terjadi menyebakan indeks Dow Jones mengalami penurunan secara signifikan. Peningkatan indeks Dow Jones pada tahun 2004 disebabkan kondisi ekonomi Amerika dan dunia yang membaik sedangkan penurunan indeks Dow Jones terjadi kondisi krisis global yang menyebabkan krisis kepercayaan finansial di Amerika dan di dunia. Krisis subprime morgage mendorong turunnya kepercayaan masyarkat terhadap perusahaan Amerika Serikat sehingga saham-saham hampir semuanya mengalami penurunan (Muharam dan Nurafni, 2008). Selain itu juga Amerika Serikat merupakan salah satu negara tujuan ekspor utama Indonesia (Bank Indonesia, 2008 dan Bank Indonesia, 2011). Sehingga perubahan kondisi perekonomian Amerika Serikat yang akan tercermin di Indeks Dow Jones akan memberikan pengaruh bagi perekonomian Indonesia 
melalui IHSG sebagai salah satu indikator perekonomian Indonesia (Samsul, 2008 dalam Adisetiawan dan Hasminidiarty, 2011). Hasil penelitian mendukung penelitian Hayo dan Kutan (2004) tentang pengaruh pasar modal dunia terhadap pasar modal suatu Negara dan penelitian yang dilakukan Muharam dan Nurafni (2008) dan Pratikno (2009) yang menyatakan Indeks Dow Jones berpengaruh positif terhadap pasar modal Indonesia.

h) Indeks Nikkei 225 terhadap IHSG

Hipotesa kedelapan yang menyatakan bahwa diduga ada hubungan timbal balik antara Indeks Dow Jones dengan IHSG tidak terbukti, karena dari hasil analisis Granger Causality diperoleh bahwa tidak terdapat hubungan timbal balik antara Indeks Dow Jones dengan IHSG selama periode 2001-2017. Tetapi hasil analisis Regresi Berganda secara parsial (uji t) membuktikan bahwa Indeks Dow Jones mempunyai pengaruh positif terhadap IHSG selama periode 2001-2017.

Hal ini dikarenakan Jepang dan RRC sebagai negara yang saat ini paling mendominasi perdagangan di Asia. Kedua negara ini merupakan negara dengan pertumbuhan ekonomi yang paling tinggi, pertumbuhan ekonomi yang tinggi pada negara maju dicirikan teknologi komunikasi yang dimiliki negara tersebut jauh lebih unggul dari pada negara lainnya (Mariah dan Suharti, 2004). Sebagai salah satu negara tujuan ekspor Indonesia, pertumbuhan ekonomi Jepang dapat mendorong pertumbuhan ekonomi Indonesia melalui kegiatan ekspor maupun aliran modal masuk baik investasi langsung maupun melalui pasar modal (Sunariyah, 2006). Karim (2008) mengemukakan bahwa pasar modal Indonesia sudah terintegrasi dengan pasar modal dunia. Hal ini menimbulkan konsekuensi bahwa pergerakan pasar modal Indonesia akan dipengaruhi oleh pergerakan pasar modal dunia baik secara langsung maupun tidak langsung (Samsul, 2008)

\section{SIMPULAN}

Dari hasil penelitian dan pembahasan yang dilakukan sesuai dengan hipotesis yang diajukan, dengan analisis Granger Causality dan analisis Regresi Linear Berganda, maka dapat ditarik kesimpulan bahwa selama periode 20012017 terdapat hubungan kausalitas antara jumlah uang beredar (M2) dengan IHSG di Bursa Efek Indonesia, tetapi tidak terdapat hubungan kausalitas antara BI rate, inflasi, harga minyak mentah dunia, emas, kurs IDR/USD, indeks Dow Jones dan indeks Nikkei 225 terhadap IHSG di Bursa Efek Indonesia pada periode yang sama. Hasil pengujian model penelitian dengan tingkat keyakinan 99\%, diperoleh nilai adjusted $R$-square secara simultan sebesar $98,4 \%$; artinya secara bersamasama (simultan) terdapat pengaruh yang sangat signifikan antara variabel BI rate, inflasi, jumlah uang beredar, harga minyak mentah, harga emas, kurs IDR/USD, indeks Dow Jones dan Nikkei 225 terhadap IHSG di Bursa Efek Indonesia (BEI) selama periode 2001-2017, dengan kata lain perubahan ekonomi makro dan global mampu memberikan variasi yang sangat signifikan pada pola pergerakkan indeks harga saham (IHSG) di pasar modal Indonesia (BEI) selama periode 2001-2017. Hal ini juga dibuktikan dengan besarnya nilai korelasi ekonomi makro (BI rate, inflasi, jumlah uang beredar dan kurs IDR/USD, harga minyak mentah dunia dan harga emas dunia), dan integrasi pasar modal dunia (indeks Dow Jones dan Nikkei 225) terhadap IHSG di Bursa Efek Indonesia selama periode 2001-2017, yaitu sebesar $99,3 \%$. Hal ini menunjukkan terjadi hubungan yang sangat erat antara 
ekonomi makro dan integrasi pasar modal dunia terhadap indeks pasar modal Indonesia selama periode 2001-2017. Namun, secara parsial laju inflasi yang terjadi di Indonesia pada periode yang sama tidak memberikan pengaruh yang signifikan terhadap pergerakan indeks pasar modal Indonesia.

\section{DAFTAR PUSTAKA}

Adisetiawan., R, 2017, Globalisasi Pasar Modal Dunia dan Pengaruhnya Terhadap Pasar Modal Indonesia, Ekonomis: Journal of Economics and Business, 1(1): 10-17

Adisetiawan., R, and Surono, Yunan., 2016, Indonesian Capital Market Efficiency, British Journal of Economics, Finance and Management Sciences, 11(1): 108-121

Adisetiawan., R, 2012, Analisis Pengaruh Inflasi, BI rate, dan Nilai Tukar Mata Uang terhadap Return Indeks LQ45, Jurnal Ekonomi, 27(1):86-96

Adisetiawan., R, 2011, Keseimbangan Jangka Panjang antara Variabel Makroekonomi dengan Indeks Harga Saham, Trikonomika, 10(2):72-84

Adisetiawan., R, dan Hasminidiarty, 2011, Analisis Pengaruh Variabel-Variabel Makroekonomi dan Mikroekonomi Terhadap Risiko Investasi Saham, Jurnal Ekonomi, 26(2):159-174.

Ang, Robert., 1997, Buku Pintar : Pasar Modal Indonesia, First Edition Mediasoft Indonesia

Bank Indonesia, 2008, Outlook Ekonomi Indonesia 2008-2012: Integrasi Ekonomi ASEAN dan Prospek Perekonomian Nasional, Biro Riset Ekonomi Direktorat Riset Ekonomi dan Kebijakan Moneter: Bank Indonesia

Bank Indonesia, 2011, Laporan Neraca Pembayaran Indonesia: Realisasi Triwulan II-2011, Biro Neraca Pembayaran Direktorat Statistik Ekonomi dan Moneter: Bank Indonesia

Bernanke, Ben S., and Kenneth N. Kuttner, 2004, What Explaint the Stock Market's Reaction to Federal Reserve Policy, Journal of Finance, American Finance Association, 60(3):1221-1257

Erawati, Neny., \& Llewelyn, Richard., 2002, Analisa Pergerakan Suku Bunga dan Laju Ekspektasi Inflasi untuk menentukan Kebijakan Moneter di Indonesia, Jurnal Manajemen dan Kewirausahaan, 4(1):98-107.

Hayo, Bernd and Ali M. Kutan, 2004, The Impact of News, Oil Prices, and Global Market Developments on Russian Financial Markets, Working Paper No. 656, William Davidson Institute at the University of Michigan Business School

Ghozali, Imam., 2006, Aplikasi Analisis Multivariate dengan Program SPSS, BP Undip Semarang

Husnan, Suad, 2004. Dasar-dasar Teori Portofolio dan Analisis Sekuritas, Edisi Keempat, Yogyakarta, AMP YKPN.

Hermanto, dan Manurung, Adler., 2002, Pengaruh Tingkat Suku Bunga SBI, Nilai Kurs Dollar Amerika, Jumlah Uang Beredar (M2), Pembelian Bersih Investor Asing di BEJ terhadap IHSG di BEJ Periode 1998-Maret 2002, Usahawan, 33(2):112-127.

Handayani, 2007, Pengaruh Tingkat Bunga SBI, Nilai Tukar Dollar AS, dan Tingkat Inflasi terhadap IHSG di BEJ, 49(1):55-67

Jatiningsih, Oksiana., 2007, Pengaruh Variabel Makroekonomi terhadap IHSG di BEJ, Jurnal Aplikasi Manajemen, 5(1):18-25 
Kilian, Lutz and Cheolbeom Park, 2009, The Impact of Oil Price Shocks on the U.S. Stock Market, International Economic Review, 50(4):1267-1287

Kustini, 2007, Analisis Pengaruh IHSG, Tingkat Suku Bunga SBI, dan Biaya Manajemen terhadap Unit Penyertaan Reksadana, Jurnal Ekonomi dan Manajemen, 8(2):216-224

Karim, Adiwarman, 2008, Mengantisipasi Dampak Krisis Keuangan Global. Impresario, BRI, Jakarta

Lee, S.B., 1992, Causal Relations Among Stock Return, Interest Rates, Real Activity, and Inflation, Journal of Business Finance and Accounting, 17(2):55-70.

Prijambodo, Bambang., 2011, Perkembangan Ekonomi Makro Sampai dengan 18 Februari 2011, Kementerian Perencanaan Pembangunan Nasional/Bappenas, diakses 11 Oktober 2011

Pratikno, Dedy., 2009, Analisis Pengaruh Nilai Tukar, Inflasi, SBI, dan Indeks Dow Jones terhadap Pergerakan IHSG di BEI, Tesis MM, Universitas Sumatera Utara

Pasaribu, Pananda, Wilson L Tobing, Adler Haymans Manurung, 2009, Pengaruh Variabel Makroekonomi terhadap IHSG, Jurnal, Universitas Indonesia

Murwaningsari, Etty,. 2008, Pengaruh Volume Perdagangan Saham, Deposito dan Kurs terhadap IHSG beserta Prediksi IHSG (Model GARCH dan ARIMA), Jurnal Ekonomi dan Bisnis Indonesia, 23(3):178-195

Muharam, Harjun., dan M.S. Zuraedah Nurafni, 2008, Analisis Pengaruh Nilai Tukar Rupiah dan Indeks Saham Dow Jones Industrial Average terhadap IHSG di BEJ, Jurnal MAKSI, 8(1):24-42

Madura, Jeff, 2000, Manajemen Keuangan Internasional, Erlangga, Jakarta

Novianto, Aditya, 2011, Analisis Pengaruh Nilai Tukar Dolar Amerika/Rupiah, Tingkat Suku Bunga SBI, Inflasi, dan Jumlah Uang Beredar (M2) Terhadap IHSG di BEI Periode 1999.1 - 2010.6, Skripsi, FE-Universitas Diponegoro, Semarang.

Novita., Mega, Adi Setiawan, dan Nugroho., Didit Budi, 2009, Studi Kausalitas Granger Antara Nilai Tukar Rupiah terhadap USD dan AUD menggunakan Analisis VAR, Prosiding: Seminar Nasional Penelitian, Pendidikan dan Penerapan MIPA, Fakultas MIPA, Universitas Negeri Yogyakarta, 109-116.

Nugroho, Heru, 2008, Analisis Pengaruh Inflasi, Suku Bunga, Kurs dan Jumlah Uang Beredar terhadap Indeks LQ45 periode 2002-2007, Tesis MM, Universitas Diponegoro, Semarang.

Narayan, Paresh Kumar dan Seema Narayan, 2009, Modelling The Impact of Oil Prices on Vietnam's Stock Prices. Jourrnal Applied Energy, 87(2010):356361.

Sunariyah, 2006, Pengantar Pengetahuan Pasar Modal, Edisi Kelima, UPP STIM YKPN, Yogyakarta.

Samsul, M., 2008, Pasar Modal dan Manajemen Portofolio. Erlangga, Jakarta

Smith, Graham,. 2001, The Price Of Gold And Stock Price Indices For The United States.

Sudjono, 2005, Analisis Keseimbangan dan Hubungan Simultan Antara Variabel Ekonomi Makro terhadap Indeks Harga Saham di Bursa Efek Jakarta dengan Metode VAR dan ECM, Jurnal Ekonomi Teleskop, 4(7): 101-116

Suharti, Fitri Mariah dan Lydia, 2004, Analisa Pengaruh Nilai Tukar Mata Uang, Suku Bunga dan Indeks Harga Saham pada 5 Negara di Asia serta Korelasi 
Antara IHSG Indonesia tahun 2001-2003 (Studi Kasus pada Nikkei Stock Average 225 Index, Hangseng Index, Shenzhen Composite Index, Pse Index, dan Set Index, Skripsi, FE-Universitas Kristen Petra, Surabaya.

Setyastuti, 2001, Hubungan Dinamis antara IHSG dengan Nilai Tukar, Tesis MM, Pascasarjana FE-Universitas Gadjah Mada, Yogyakarta.

Sirait, Hisar., 2004, Analisis Kointegrasi Variabel Ekonomi Makro dan Bursa Asing terhadap Indeks Saham Bursa Efek Jakarta. Jurnal Ekonomi Perusahaan, 11(1):173-188.

Sulistiyo, M. Herman, 2004, Perilaku Dinamis Antara IHSG dengan Nilai Tukar Rupiah terhadap Beberapa Negara Asia sebagai Dampak dari Krisis Ekonomi dengan Metode VAR/VECM, Tesis, FE-Universitas Indonesia

Sriwardani, Fautia. 2009. Perbandingan Pengaruh Indikator Makroekonomi Global dan Indonesia Terhadap IHSG dan JII Menggunakan Model VAR dan Impulse Response Runctions, www.digilib.ui.ac.id/beranda/kata kunci/ pengaruh harga minyak terhadap IHSG (diakses pada tanggal 10 Januari 2010 jam 10.15 WIB).

Sidarta., Wahyu, 2010, Pengaruh Gejolak Harga Minyak Mentah terhadap IHSG; Bergerak Beriringan Belakangan Ini, http://www.vibiznews.com/column/stock/2010/12/13/pengaruh-gejolakharga-minyak-mentah-terhadap-ihsg-bergerak-beriringan-belakangan-ini, (diakses pada tanggal 13 Desember 2010 Jam 13:35 WIB).

Sitinjak, Elyzabeth Lucky Maretha dan Widuri Kurniasari, 2003, Indikatorindikator Pasar Saham dan Pasar Uang yang Saling Berkaitan ditinjau dari Pasar Saham sedang Bullish dan Bearish, Jurnal Riset Ekonomi dan Manajemen, 3(3):156-177

Sa'adah, Siti dan Yunia Panjaitan, 2006, Interaksi Dinamis antara Harga Saham dengan Nilai Tukar Rupiah terhadap Dollar Amerika Serikat, Jurnal Ekonomi dan Bisnis, 26(1):46-62

Twite, Gary,. 2002, Gold Prices, Exchange Rates, Gold Stocks and the Gold Premium, Australian Journal of Management, 27(2):123-140

Theresia, Puji Rahayu., 2002, Analisis Pengaruh Nilai Tukar dan Suku Bunga terhadap IHSG di BEI, Jurnal Ekonomi dan Bisnis Indonesia, 22(1):294312.

Utami, Mudji., \& Rahayu, Mudjilah, 2003, Peranan Profitabilitas, Suku Bunga,Inflasi, dan Nilai Tukar dalam mempengaruhi Pasar Modal Indonesia Selama Krisis Ekonomi, Jurnal Manajemen \& Kewirausahaan, 5(1):123131.

Valadkhani, A, Chancharat, S and Harvie, C, 2006, The Interplay Between the Thai And Several Other International Stock Markets, Working Paper 06-18, Department of Economics, University of Wollongong.

Widjaja, Emilia., 2004, Analisis Pengaruh Inflasi terhadap Tingkat Risiko Saham (Studi Kasus pada Saham-saham Ketegori LQ45 tahun 2001-2002), Kinerja : Ekonomi dan Bisnis, Atmajaya, 46(1):55-67.

Wiyani, W., dan Wijayanto, A., 2004, Pengaruh Nilai Tukar Rupiah, Tingkat Suku Bunga Deposito dan Volume Perdagangan Saham terhadap Harga Saham, Jurnal Keuangan dan Perbankan, 9(3):56-73. 